\title{
THE BIRTH OF NURSING AT THE INCEPTION OF THE FRANCOISM IN SPAIN (1939-1942)
}

\author{
María del Carmen Giménez Muñoz ${ }^{1}$
}

\begin{abstract}
${ }^{1}$ Ph.D. in Contemporary history. Professor, Departamento de Enfermería. Universidad de Sevilla. Sevilla, Spain. E-mail: mcarmengimu@ us.es

ABSTRACT: This study is aimed at analyzing the creation of the Nursing science in the early days of the Franco regime in Spain (19391942). This was a qualitative and historical study, that used as documentary sources, printed newspapers in different regions of Spain. Results. The importance of the work of nursing during the state of need, hunger, misery, for the post-war Spanish population was identified. Nurses with this attitude and commitment to one another, facilitated the administration of food for the needy, stocked up on clothes for those who were suffering from cold, and taught hygiene principles to mothers in order to reduce the high mortality rate of children and youth who was suffering due to the performance of social assistance. Therefore, in the face of adversity, nurses attended and cared for the children, sick, elderly and the poor. It is concluded that the humanitarian work of nurses became an element of repression, distributing benefits in exchange for an ideological model
\end{abstract}

DESCRIPTORS: Nurses. Social welfare. War. Health.

\section{EL NACIMIENTO DE LA ENFERMERÍA DURANTE LOS INICIOS DEL FRANQUISMO EN ESPAÑA (1939-1942)}

RESUMEN: Estudio con el objetivo de analizar el nacimiento de la Enfermería en el primer franquismo en España (1939-1942). Estudio histórico cualitativo, cuyas fuentes documentales utilizadas fueron los periódicos impresos en diferentes regiones de España, en el periodo 1939-1942. La importancia del trabajo de los cuidados de enfermería en el estado de necesidad, hambre, miseria, en que había quedado la población española tras el conflicto bélico. Las enfermeras con su actitud y compromiso hacia el otro, facilitaron la administración de alimentos a los más necesitados, abastecieron de ropas a los que padecían frio y enseñaron principios de higiene a las madres para reducir la elevada tasa de mortalidad infantil y juvenil que se padecía, puntos cruciales para la actuación de la ayuda social. Por tanto, ante la adversidad, las enfermeras atendieron y cuidaron a los niños, a los enfermos, a los ancianos y a los pobres. Se concluye que la labor humanitaria de las enfermeras se convertía en un elemento de represión distribuyendo prestaciones a cambio de la exigencia de un modelo ideológico.

DESCRIPTORES: Enfermeras. Asistencia social. Guerra. Sanidad.

\section{O NASCIMENTO DA ENFERMAGEM DURANTE O INÍCIO DO FRANQUISMO NA ESPANHA (1939-1942)}

RESUMO: Estudo com o objetivo de analisar o nascimento da enfermagem sob o início de Franco na Espanha (1939-1942). Estudo histórico qualitativo documental, cujas fontes utilizadas foram os jornais impressos em diferentes regiões da Espanha, no período 1939-1942. Os resultados revelaram a importância do trabalho da enfermagem no estado de necessidade, fome, miséria para a população espanhola após a guerra. A atitude e compromisso dos enfermeiros com o outro facilitaram os cuidados aos necessitados em termos de alimentação, roupas e ensino de princípios de higiene para as mães a fim de reduzir a elevada taxa de mortalidade de crianças e jovens necessitados de assistência social. Portanto, diante da adversidade, enfermeiros participaram dos cuidados para as crianças, os doentes, os idosos e os pobres. Concluiu-se que o trabalho humanitário dos enfermeiros tornou-se um elemento de benefícios repressão distribuição em troca da exigência de um modelo ideológico.

DESCRITORES: Enfermeiras. Assistência Social. Guerra. Saúde. 


\section{INTRODUCTION}

During the first decades of the twentieth century, several nationalist movements, illiberal, totalitarian, and anti-Marxist emerged in Europe. Their influence initiated small and diverse nuclei, labeled as fascist in character, during the 1930s. Among these movements, one had special relevance in the events that occurred, in a extremely fast manner, and that would lead Spain to a Civil war and subsequent dictatorship. The Phalanx, a movement led by José Antonio Primo de Rivera, was able to order, in a short time, the political doctrine of a fascist regime. ${ }^{1}$

Addressing this kind of issue requires us to a briefly refer to the historical period immediately preceding this, so that the monumental regression experienced by women due to the introduction of the new Francoist State can be understood. The second Republic conducted a series of gender policies, which aimed to contribute for the modernization of the Spanish society. For the first time in our history, women broke through barriers that prevented them access to political rights and, in particular, to the vote. The Constitution of 1931 gave them that opportunity, as well as other rights that would have enabled their emancipation: divorce, positions of employment, better working conditions. ${ }^{2}$

However, the model of a woman that was established at the end of the Civil War, by the military regime, represented a remarkable setback. The Franco dictatorship wanted to impose a model of organic society with a gender policy regulated by civil legislation, denying any type of individual autonomy to women, and the detention of women in the domestic sphere, ensuring their subordination*.

The postwar period was a time of deprivation and survival. The battle against hunger forced people to eat potato peels, orange peels and various food residues that were not enough to prevent serious epidemic cycles of tuberculosis, typhoid or dysentery. A great majority of men, women and children survive due to beneficent help, which embodied precisely the National Agency of Social
Relief of Spanish Traditionalist Phalanx (Falange Española Tradicionalista - FET) and the Boards of National Syndicalist Offensive (Juntas de Ofensiva Nacional Sindicalista - JONS). ${ }^{3}$ The main mission was, at first, to alleviate the needs resulting from the war and, later, the disastrous effects of autarky by the absence of a coherent social policy**. Food, education, supply of clothes and hygiene were crucial points for the performance of social assistance. However, nurses and rural visitors played a role in the dissemination of care and charity according to the totalitarian regime's philosophy.

The aim of this study was to analyze the establishment of Nursing under the early Franco regime in the period from 1939-1942, in Spain. With nurses and rural visitors, in the guise of charity, support and understanding of those cared for, a network towards moral and ultimately juridical control and sanction was articulated. This handling with kid gloves was hiding the cruel power of the police that was about to come.

\section{METHOD}

This was an historical, social qualitative study, using documentary research as a method of collecting and analyzing data. The methodology used was the consultation of materials printed from 1939 to 1942, conducted in various newspaper archives of Spanish provinces: the Newspaper archives of the Provincial council of Almería and, the Municipal newspaper archive of Seville. In relation to the first, the semiannual newspaper, Yugo, was consulted between 1939 to 1942 . The newspaper was semiannual, resulting in two volumes by year, from January to December, as well sd in another Spanish province, in the Municipal newspaper archive of Seville with the consultation of the newspapers: Falange Española (FE), ABC and the Correo de Andalucía. Franco's Spain maintained the press law of 1938, designed for a tight control of the publications. Its most important characteristic was prior censorship and the "Orders", by which the Ministry of information and tourism could

* It was an anti-feminist position expressed in the Labour Law of 1938, which promulgated the following: "In particular this law will prohibit night work for women and children, and also will regulate home work and set the married woman free off workshop and factory". Official Gazette, March 10, 1938; 47.

** The economy of Spain, during the period of autarky, describes the period of almost permanent economic crisis in Spain since the end of the Civil War until the 1950s that led to a serious deterioration in the living conditions of citizens, the growth of misery, black market, that marked the most serious levels of declination of the welfare of the population. 
command the inclusion of items, including editorials with a particular trend or content.

Once documents were collected and processed, documentary interpretation was performed, aiming to select and synthesize the information in documentary identification cards and content analysis sheets in accordance with the work plan, as well as the development and computerization of the documentary references, synthesis of content, and final drafting. Therefore, the nuclear part of the methodology developed was an exhaustive analysis obtained from the archive sources, literary, legislative and political discourse.

\section{RESULTS AND DISCUSSION}

\section{The work of social assistance and the nurses}

At the end of the civil war, Spain was a ruined country in which the loss of human lives was added to the destruction of property. The autarchic economic model imposed by General Franco aimed to produce self-sufficiency in the country, using domestic production rather than imports. The ultimate goal was not only economic independence but the industrialization of the nation. The Franco regime resorted to two explanations to justify the adoption of autarkic economic policy as inevitable: on the one hand, the consequences of the Civil war, and on the other the World War II. ${ }^{4}$

Thus, the economic policy remained anchored in the dictates of autarky in the years following the civil war; smuggling and black markets prospered, together with widespread tax evasion. ${ }^{5}$ The main beneficiaries of corruption were the groups' adherent to the regime, since they were the only ones who handled public funds and had commercial and industrial powers. ${ }^{6}$ Thus, a huge bureaucracy that hindered the management of scarce resources was generated and multiplied the administrative irregularities of auditors, mostly of internal trade. ${ }^{7}$

The Decree of the Ministry of Industry and Trade, of May 14, 1939, established a system of rationing of essential items to ensure supplies for the population. ${ }^{8}$ This description made by the Provincial Headquarters of Alicante in relation to supplies was about one situation:

"[...] terrifying, the province was without bread and without the possibility nor the perspective of ac- quiring it. More than four months ago the oil was not rationed; other products, it does not even mention. Practically we would be all corpses in all the province, if we were eating of the rationing of the Delegacion de Abastos (Agency of Abastos)" .9: 9 Therefore, the lack of supplies became one of the most serious problems that the new regime confronted. ${ }^{10}$ It was merely a long-awaited consequence of the regime, in an attempt to make definitive the submission of those defeated in the war. ${ }^{11}$ On the other hand, some studies, based on official reports sent by provincial controls, demonstrate the constant concern of the Francoist authorities about the situation of misery that was impacting the population, as a result of disastrous adopted economic policies. ${ }^{12}$

However, the significance of the new social protection measures were innovative. So, for example, the Family Allowances Act, of 1938, granted salary supplements to male heads of households based on the number of children, ending the motherhood protection, launched in 1931, and rewarding, on the other hand, paternity. In 1939, old-age and disability insurance (Seguro Obrero de Vejez e Invalidez - SOVI) began and, in 1942, Compulsory Health Insurance (Seguro Obligatorio de Enfermedad-SOE). Perhaps the scope of these insurances was very limited, since these measures only affected employees, and in many cases not even all of them, which meant that there were men, women and children as a part of the production process, but who did not have the benefits of social protection. ${ }^{13}$

Then, the only solution left for those men, women and children was the old formula of beneficence, which represented precisely the National Delegation of Social Relief of FET and the JONS, who cared for those who were identified as impoverished, a context of extreme poverty, both with heavy dependence on those who had lost the war as well as the most underprivileged sectors among the victors. ${ }^{14}$ It was one of the keys to understanding the meaning of emergence and consolidation of an organization such as the Social Aid, which was one of the instruments for social control in the New Francoist Spain. Mercedes Sanz Bachiller inaugurated, in October of 1936, a collective dining room for children in Valladolid, the basis for the most symbolic welfare institution in the Franco Regime. Initially, she and her adventurous partner, Javier Martinez de Bedoya of JONS, presented this project as an attempt to alleviate the 
needs that had generated insurgency and the war: the Winter Relief. ${ }^{16}$ Their ideals were reduced to the spirit of sacrifice and self-sacrifice for work, imitating the Germans, from the name German Winterhilfe (Winter Relief), piggy banks and emblems of organizational concepts exceeding the pure assistance limits were filled with political content. Some years later the great work that Caudillo reserved for the most needy, the National Delegation of Social Aid, was created. ${ }^{17}$ The results did not stop with the opening of neighborhood dining areas and kitchens, with the organization of necessary fund raising activities. So, the leaders of Social Aid strove to prove that it was not a charity, as occurred with a traditional charity, but that it was providing social justice. ${ }^{18}$ According to news accounts:

"Social Aid" is the concrete crystallization of all social benefit policies of the Phalanx, in conjugation with the strength and activity of the State. "Social Aid" included the following sections: "Winter Relief", "National-Syndicalist Organization for the Protection of Mother and Child", "Aid for the Sick" and "Aid for the Elderly". ${ }^{19: 8}$

It would include, "children's dining rooms, neighborhood kitchens (for unemployed adults) and defense of the child, which in turn was divided into households and promotion of the family work. The national syndicalist protection of mother and child consisted Preintra-natal dispensary (office, equipment, dining areas, mutual societies and subsidies); the Child Care Dispensary (dining area for mothers, clinics, home work for the mother and mutuality); nursing rooms (in industries); nurseries (children aged one month to three years) and kindergartens (children aged three to seven years). This work required in certain areas, a provincial or territorial Motherhood and Child Care Institute. The Aid for the sick in our work is not provided through medicines or technical elements, but has the following sections expressed: Supply of clothing, diet kitchens (in them three types of menus suitable for all kinds of disease are prepared and distributed). Useful supplies (for example, a mattress, a portable stove, etc.) and finally, visiting nurses helping the sick from the National Syndicalists". 20:2

Therefore, visiting nurses had an important role in the reconstruction of the new state by visiting humble homes, helping mothers with their children's care, disseminating hygiene standards to prevent epidemics. A nursing degree could be achieved by a course, so the press appealed for Social Nurses:
"The comrades who have to require the diploma are kindly requested to be there during this day, from 10am to $2 \mathrm{pm}$ and $4 \mathrm{pm}$ to $7 \mathrm{pm}$, at the Administration of FET and JONS, located in the Provincial Headquarters for this purpose. Almeria, February 2nd, 1940. For God, for Spain and its National syndicalist revolution". 21:4

On the other hand, the decree issued in October of 1937, provided a formal basis for the new Social Service and indicated Social Assistance as a favorable sector where Social Service could be to performed, entrusting the task of putting it into practice to the National Delegation. ${ }^{22}$ Pilar Primo de Rivera, delegate of the Women's Section, fought to have those extensions of Social Service allocated to the Women's Section. Indeed, according the decree of December 28, 1939, Social Service was transferred from the National Delegation of Social Aid to the Women's Section. ${ }^{23}$

Theoretically, pursuing Social Service was preparing women for domestic life, as a mother, and to acquire a general education about the home. In any case, seeking an education that predisposed them to work in social tasks, such as nurses, cooks, seamstresses, among others, and to allow them to provide services, if necessary. ${ }^{24}$ Thus, since the newspapers the nurses were convened:

"Nurses applying for "Social Aid" positions are requested to attend the Provincial Delegation of $<<$ Social Aid $>>$, today the 12th at $5 \mathrm{pm}$, for an aptitude test ${ }^{\prime \prime} .{ }^{25: 5}$

Thus, the nurse team of the Phalanx was created at the beginning of the decade of the 1940s. In January, the Yugo newspaper announced: "The nursing team of the Phalanx is created" ${ }^{26: 7}$

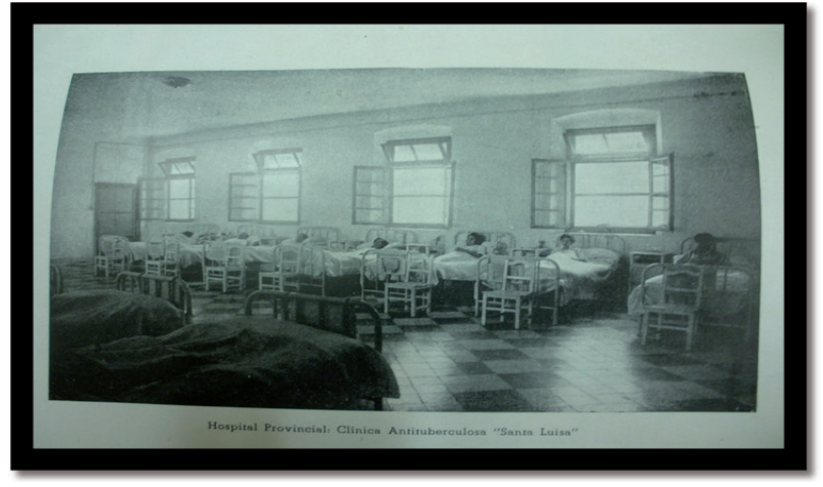

Source: Archives of the Provincial Council of Seville, 1942

Figure 1 - Hospital de las Cinco Llagas de Sevilla 1942 
The creation of the nursing team of the Phalanx

On January 3, 1942, the Official Gazette published an Act of the Head of the state which provided for the creation of the nursing team of FET and JONS, as a result of the agreement reached in the Council of Ministers. Thus, nursing would report directly to the National Delegation of Women section. ${ }^{27}$ Nurses with the title of nurses, and those who would obtain this in the future, could be part of that automatically. ${ }^{28}$ Similarly, the establishment of a school composed of the Medical Corps of Military Health was available. ${ }^{29}$ The Yugo reported the following:

"Nurses found themselves, available with the same promising spirit of sacrifice and efforts, two paths that will diverge, with the specialties in service, two different behaviors and a single goal: the health of the country, with nurses caring during peace and in times of war, and with two titles that will be a source of pride for those that achieve them. The titles of specialties that women can aspire once they possess the title of nurse of F.E.T. and J.O.N.S., are those corresponding to the two sections instituted: Visiting nurses and Military nurses. One can see how far reaches the desire of the state and the concern of the party to take advantage and use the enviable condition of the comrades of the Women's Section". 30:6

The press appealed to all nurses in order to implement the law:

"All nurse comrades must pass through this Women's Health Section Regiment during office hours, before the 28th of this month, when the deadline for title exchange is over. Likewise all comrades who have not yet applied to the Nurses Corps, in the way that it has been done so far, must quickly do so, because there is little time remaining and when the deadline is over, admission to the Nurses Corps will be definitely closed by request and only those who attended our courses will be admitted from then on. It is necessary that all member nurses know their deadline to apply for the Corps, to avoid later complaints".31:9

Therefore, because the title of Traditionalist Spanish Phalanx already had an official status within the State, the provisory titles had to be exchanged for the definite ones. Now, "this exchange will only be made for the comrades who have an excellent service record". 31:9

It should be recalled that at the beginning of the Civil War, still in the early stages of fighting, that the Women's Section was quick to mobilize all its affiliates because that is what the circumstances required, paying special attention to health services: war hospitals, first aid units of the Army, vanguard infirmaries, laboratories, surgical teams, etc. Then it was necessary to channel the efforts of those who were enthusiastic, full of good will, without a doubt, but lacking technical preparation for the mission assigned to them. ${ }^{32}$ The fighting required a continuous increase in the number of nurses, due to which the first training mini courses emerged. There were two categories of nurses: the one called Traditionalist Spanish Phalanx and the Social Nurses, each of which had a specific and concrete task. Once they completed these minicourses, they were give the corresponding title officially recognized for all purposes by the Government, dated April 16, 1937.33 Yugo says:

"Of this exemplary behavior of the nurses, who served in various positions to which they were assigned during the war, often in the line of fire, there will rise the notion that glorious deaths happened during acts of service: four were injured, many others mutilated, and two fell into enemy hands. To reward these facts, 13 were awarded the Collective Laureate of San Fernando; 50 were awarded the Red Cross of Military Merit; and the Gold $\ddot{Y}^{\prime \prime}$, which only has been awarded to a total of seven comrades of the Women's Section; ten were awarded the Silver or Red " $Y$ ". 34

Once the Civil War was over, the Phalanx women were awarded various commendations for their exemplary service. The Women's Section Rewards Service was created with a Permanent Board of Rewards as a liaison with the General Secretariat, thereby founding a particular award named " $Y$ ", in honor of Isabel the Catholic. The first news on the granting of these awards was published in May of 1939, which narrated the great concentration of the Women's Section in honor of Caudillo in Medina del Campo. In the aforementioned concentration, individual gold " $Y$ " were awarded to comrades fallen during the war, and the silver individual "Y" were awarded to comrades who were distinguished by different events during the war. The Spanish women, represented with dignity, had a great concentration from Medina del Campo. They paid a fervent and patriotic tribute of gratitude to the caudillo (leader) and the army. ${ }^{35-37}$ It should be 
noted that, in addition to adopting the emblem of the bow and arrows, the Women's Section coveted Isabel the Catholic and St. Teresa of Jesus as role models and symbols of action.

Two of those nurses who received the gold " $Y$ " were Maria Luisa Terry, who died helping a wounded soldier, and Agustina Simon, killed "by the horde occupying the place of Belchite" ${ }^{38: 6}$ Maria Luisa Terry was the local chief in Puerto Real in the early days of the war. After leaving Ronda, holding the position of vanguard nurse, she was later attributed to the Seseña infirmary, where she was severely wounded in September of 1937, and died in the Hospital de Griñón. The other nurse, Agustina Simon, did not want to leave Belchite, where she also found death. The aforementioned collaborator highlights the work of nurses when he wrote the following:

"we want to deal with the silent, admirable and dedicated work as shown by other comrades of the Women's Section engaged in the task of home care or care and attention to the little ones provided in multiple institutions created for this purpose. In addition to these services, they kept vigil so that there were always clean clothes for the soldiers. For this purpose, there were fixed and mobile laundry rooms served by them: 1,140 comrades worked in these services and the number of washed garments amounted to 8,538,221. In establishments called "Soldier Rest", set up in San Sebastian and Seville, so that nothing was missed by the combatants during their leave, 400 affiliates worked, attending a total of 17,892 soldiers. We deal exclusively with services performed by nurses and we do not cite, therefore, another series of tasks entrusted to the Women's Section, although they could be more or less directly related to infirmaries and hospitals, or care and attention provided to those who fought in occupation fronts in defense of Spain ". 38

In 1942, the Women's Section of FET and JONS gave the collective red " $Y$ " to all those Phalanx women who had rendered outstanding services in hospitals during the liberation war. In this way, they would be entitled to this recognition provided they met the following conditions:

"One hundred and eighty days of service as nurses or nurse auxiliaries in vanguard hospitals; 250 days of service as nurses or nurse auxiliaries in hospitals with infectious diseases or night shifts; 365 days of service as auxiliary nurses in hospitals not covered above. The requests can be presented at the Provincial Delegation of the
Women's Section, Almagro 36, Disclosure Department, as soon as possible because the deadline for submission is the 31st of this month". $39: 8$

After a year since the enactment of the law establishing nursing, there remained a lack of war nurses in the Military Health Section. Thus, the dictator ordered the organization of the first war nursing courses for the Women's Section, according to the National Delegation of Health, following a plan of theoretical and practical studies. The future mission would be to practice in war hospitals. This was publicized by El Correo de Andalucía:

"For the first time one can count on a precious auxiliary Female Corps of the Sanitary Technical Corps, which, if necessary, will provide valuable services not only due to their knowledge and skills but due to their discipline, as framed within the Women's Section of FET and JONS ". ${ }^{40: 7}$

This news was also echoed in the Yugo:

"This law has a broad sense of precision, because it is guided to count on female staff with a required and sufficient ability for missions that they have to perform and that require expertise. This staff will be fully trained, and will belong exclusively to eligibilities of the Women's Section". ${ }^{11: 6}$

Therefore, the Phalanx offered in each of its formative stages a new balance of reality with the establishment of new services. In this case, with the official creation of the War Nurses specialty. However, Yugo noted that:

"These new services are met with high Falangist decision and spirit, for the comrades of the Women's Section are aware of the mission that the Party and the Caudillo imposed on them, solving an action problem that is highly decisive for the destinations in Spain. This mission, deep and profound, translates into the educational work of women, in their exemplary conduct to occupy the position of wife and mother in the Christian home with dignity". 42:4

In Almeria, in the auditorium of the School of Arts and Crafts, the official closing of the nursing minicourse, organized by the Provincial Delegation of the Women's Section, was held. The presidential table consisted of the Civil Governor and Provincial Chief of the Movement, with the representation of the military government, the Commander of the Navy, the accidental Mayor, the Attorney General and the Provincial Delegate 
of the Women's Section. First Mercedes Alonso, Provincial Deputy of the Women's Section, made the following speech:

"During the war, when the Women's Section was required to cover the nursing services in the hospitals, there was a need to organize training courses in order to initiate them through their development for the work awaiting them. Provisionally,40-day mini courses were organized by the National Delegation of Health, according to the Women's Section. Ten thousand affiliates of the Women's Section took their positions in hospitals, infirmaries, surgical teams, etc. In vanguard and rearguard our comrades worked tirelessly throughout the campaign, withou haggling any effort or sacrifice. After the war, we have before us a new task, also full of constant effort. And this new task just began, of which I, the Caudillo, will now speak, rewarding the efforts of nurses of the Women's Section and recognizing their services. Dated January 3, 1942, the Nurses Law is promulgated, through which the Nurse Corps of FET and JONS is open, granting official recognition to this title and creating the Visiting Nurses and War Nurses. In order to answer this confidence, and the official title granted only to those comrades who really deserve it and have a minimum of technical knowledge, we proceeded to make careful selection. First by reviewing service records, not only of the campaign season but this second stage of labor, when it has become clear who the true Falangist was. Once this initial selection was done, a revalidation test was performed, because our nurses must have a minimum knowledge. Once this selection is over, they will remain permanently in the Official Nurse Corps of FET, and this, like all services of the Phalanx, obliges them to meet with exact discipline and magnificent spirit the services with which they are entrusted by the command". 43:3

In 1944, the National Deputy of the Women's Section imposed emblems on the nurses of FET and JONS. The event took place in Corunna, Pilar Primo de Rivera. The National Deputy, together with all authorities and hierarchies, made the distribution of titles and emblems. The National Delegate in her speech stated that: "when receiving the titles all comrades receive a new obligation with the Women's Section of the Phalanx". ${ }^{44: 6}$ At the heart of the matter what was broadcast was an offer of a good image of a true repressive state. Counting on nurses was essential to channel female mobilization towards the right direction to build a New State. ${ }^{45}$ According to periodical testimonials:
"It is very easy to understand the importance of this task imposed by the Phalanx to the women, and of which such good results are being received. But its importance is even bigger, considering that part of the sanitary work is aimed at reducing child mortality, making a happy and smiling future possible, in which they can provide their perfect service to the Fatherland. This involvement of women is essential if one wants to extensively address the problem, as only they are able to bear the sacrifices and disappointments that sometimes the service they perform tends to carry with it, and to which they always render themselves with unique vocation and admirable enthusiasm." $46: 4$

In Almeria, an official nine-month nursing course was ordered by the National Delegation of the Women's Section, and organized by the Provincial Department of Divulgation and Social Health Care. ${ }^{44}$ It was inaugurated under the chairmanship of the Provincial Deputy, Mercedes Alonso, the Provincial Deputy for Health, the physician Martinez Zamora; the Provincial Assessor of the Women's Advisory Section, the physician Soriano Romera, and the Provincial Secretary, Durbán. The Provincial Deputy spoke about the story of how nursing was born within the Women's Section. Yugo gathered much of her speech:

"[...] at the beginning of the war, our comrades were covering the nursing services in all hospitals and then it was necessary to organize some 40-day courses in order to start them in the work that they would later develop. The National Deputy knew that this preparation was not enough but the circumstances did not allow for further study, supplying the lack of training in a spirit of self-sacrifice". $48: 7$

Following the same journalistic testimonials,

"We have no doubt that from this new course, there will be a large number of trained comrades who will complete the technical work of physicians and will be willing to lend their valuable cooperation at all times". ${ }^{49: 8}$

On the other hand, in Santander, the National Deputy of the Women's Section, Pilar Primo de Rivera, gave emblems and membership cards to fifty nurses of the Women's Section. ${ }^{50}$

\section{FINAL CONSIDERATIONS}

In light of the uncovered ideas, the NationalSyndicalist Movement, single party in the Franco dictatorship in Spain, developed several controlling 
mechanisms to ensure the consolidation, enforcement and compliance with its ideology. To carry out this work, they used their women's organization, the Women's Section, which was responsible for the training of Spanish women.

These women were in charge of feeding the needy, educating the children, supplying clothes for those who lacked them, hygiene, crucial points for the performance of social assistance. In this regard it is worth noting the importance of the work of nurses and rural visitors, their duty to the country for which they launched themselves to perform their task, without objection, unceremoniously and without demands, except of themselves. They supplemented with their dedication and work the shortage of materials and means. The service to the country was based on the performance of tasks in the role that the national-syndicalist ideology attributed to women, because their work was always regarded by others and by themselves as secondary.

Now, nurses and rural visitors, under the guise of charity, support and understanding for the unbecoming, articulated a network of social control through comprehensive study of the situation of the needy family. The humanitarian work would become an element of repression for distributing benefits in exchange for the requirement of an ideological model. Such was the importance of their work that on January 3, 1942, the Act provided for the establishment of the Traditionalist Spanish Nurses Phalanx and of the Boards of the National Syndicalist Offensive following the agreement reached in the Council of Ministers, which depend directly from the National Delegation of the Women's Section.

The Women's Section was used by the General Franco regime not only to achieve the subjugation and education of women, but to cover almost all of the issues related with shortages and economic and social needs. Franco built his own model of women between traditional and conservative influences of the prevailing Catholicism, one of the fundamental pillars of legitimacy. They never wanted to recognize the true value of the work done, except to praise them from the point of view of charity and sacrifice;not as necessary, useful or essential

It is also seen that from the belief that indi- viduals are profoundly unequal, the perception of women was of a lower spiritual and intellectual being, who lacked a social and political dimension and had a clear vocation of housewife and mother. Therefore the Franco regime does not hide its intention to oppose feminist tendencies outlined during the Second Republic, of a reformist and democratizing spirit.

The strong character of the Social Service on the female world meant a way to socialize and generalize collaboration in the national task of assisting and rebuilding the Fatherland. Thus, the Women's Section assumed important care functions, particularly in the health sector, given the context of extreme poverty and pauperism existing in Spain in the 1940s.

In short, the Women's Section would be an indoctrinating organism for the established power of Francoism that served as support for nationalism and the actions arising from the war.

\section{REFERENCES}

1. Payne, SG. Mi primer encuentro con José Antonio Primo de Rivera. Aportes: Rev Historia Contemporánea. 2002; 17(50):5-11.

2. Corcuera Atienza, FJ. El constitucionalismo de entreguerras y la Constitución Española de 1931. Historia Contemporánea.1991; 6:15-46.

3. Giménez Muñoz MC. Una aproximación al estudio del Auxilio Social en la capital almeriense (1939-1958). Aposta. Rev Ciencias Sociales. 2011; 51:1-27.

4. López Cano J. La Obra Nacional de Auxilio Social: evolución, situación y perspectivas. In Problemas fundamentales de Beneficencia y Asistencia Social. Madrid (ES): Secretaría General Técnica del Ministerio de la Gobernación; 1967. p.93-105.

5. Del Arco Blanco MA. El estraperlo: pieza clave en la estabilización del régimen franquista. Historia del Presente. 2010; 15: 65-78.

6. Barciela C. El mercado negro de productos agrarios en la posguerra, 1939-1953. In Fontana J, editor. España bajo el franquismo. Barcelona (ES): Crítica; 1986. p. 192-205.

7. Christiansen T. Intervención del Estado y mercado negro en el sector oleícola durante el primer franquismo en Historia Agraria. Rev Agricultura e Historia Rural. 2002; 27:221-46.

8. Boletín Oficial del Estado (en adelante B.O.E.), 17 de ma 1939; 85. 
9. Molinero, C, Ysàs, P. Las condiciones de vida y laborales durante el primer franquismo. La subsistencia. ¿Un problema político? VII Congreso de la Asociación de Historia Económica, Zaragoza, 19-21 de septiembre del año 2001. Disponible en internet: http://www.unizar.es/eueez/cahe/molinero.pdf

10. Comín Comín F. La hacienda pública en el franquismo autárquico 1940-1959. Madrid (ES): Editorial Crítica; 2003.

11. Richards M. Un tiempo de silencio. La guerra civil y la cultura de la represión en la España de Franco. Barcelona (ES): Crítica; 1999.

12. Molinero C, Ysàs P. El malestar popular por las condiciones de vida. ¿Un problema político para el régimen franquista? Ayer. 2003; 52: 255-82.

13. González Murillo, P. La política social del franquismo: el Seguro Obligatorio de Enfermedad. Aportes: Revista de Historia Contemporánea. 2005; 20 (57): 62-76.

14. Carasa Soto P. La revolución nacional-asistencial durante el primer franquismo (1936-1940). Historia Contemporánea. 1997; 16: 89-140.

15. Cenarro Lagunas A. La sonrisa de Falange. Barcelona (ES): Crítica; 2005.

16. Orduña Prada M. El Auxilio Social (1936-1940). La etapa fundacional y los primeros años. Madrid (ES): Escuela Libre Editorial; 1996.

17. Giménez Muñoz MC. La asistencia social en Sevilla: del auxilio de invierno al auxilio social (1936-1939). Hispania Nova. Historia Contemporánea. 2009; 9: 1-38.

18. Giménez Muñoz MC. Las tareas asistenciales de la Falange Femenina durante la guerra civil en la capital hispalense. Ámbitos: Rev Estud Ciencias Sociales Humanidades. 2010; 23: 61-72.

19. Del Auxilio de Invierno al Auxilio Social. ABC, 1937, may 19; 8 .

20. Tarea del Auxilio Social. ABC, 1937, may 20; 2.

21. Enfermeras Sociales. Yugo, 1940, feb 2; 4.

22. La aportación de la mujer española al servicio de la Patria y del Estado. F.E., 1937, oct 10; 6.

23. Gallego Méndez MT. Mujer, falange y franquismo. Madrid (ES): Taurus, 1983.

24. Almansa Martínez P, Ruíz R. La otra dictadura. El régimen franquista y las mujeres. Madrid (ES): Universidad Carlos III; 2007.

25. Auxilio Social. La Vanguardia Española, 1940, mar, $12 ; 5$.

26. Se crea el Cuerpo de Enfermeras de la Falange. Yugo, 1942, ene 3; 7.
27. ML Souza, VVB Sarton, MICS Padilha, ML Prado. O cuidado em enfermagem: uma aproximação teórica. Texto Contexto Enferm. 2005; 14(2):266-70.

28. Bernabeu Mestre J, Gascón Pérez ME. Historia de la enfermería de salud pública en España (1860-1977). Alicante (ES): Universidad de Alicante; 1999.

29. La creación del Cuerpo de Enfermeras de la Falange. Yugo, 1942, ene 13; 4.

30. Las mujeres de Falange en la paz y en la guerra. Yugo, 1942, eno 16; 6.

31. Falange. Yugo, 1942, feb 13; 9.

32. Sánchez López R. Mujer española, una sombra de destino en lo universal. Trayectoria histórica de Sección Femenina de Falange (1934-1977). Murcia (ES): Universidad de Murcia; 1990.

33. Boletín Oficial del Estado (en adelante B.O.E.), 1937, abr 24; 52 .

34. Creación del Cuerpo de enfermeras de FET y de las JONS. El Correo de Andalucía, 1942, ene 15; 11.

35. ABC, 1939, may 31; 8.

36. La Sección Femenina rinde homenaje a Franco en Medina del Campo. Yugo, 1939, may 31; 5.

37. Las mujeres de España ante Franco. Correo de Andalucía, 1939, may 31; 4.

38. Creación del Cuerpo de enfermeras de FET y de las JONS. El Correo de Andalucía, 1942, ene 15; 6.

39. Recompensas de la Sección Femenina a las afiliadas que prestaron servicio a Hospitales durante la Cruzada. El Correo de Andalucía, 1942, mar 29; 8.

40. Los cursos de enfermeras de FET de las JONS. El Correo de Andalucía, 1943, feb 2; 7.

41. Enfermeras de Guerra. Yugo, 1943, feb 3; 6.

42. Nueva misión de la mujer de la Falange. Yugo, 1943, feb $6 ; 4$.

43. El Excmo. Sr. Gobernador civil y Jefe Provincial del Movimiento, hace entrega de los Títulos de Enfermeras a las camaradas de la Sección Femenina. Yugo, 1943, jul 20; 3.

44. La Delegada Nacional de la Sección Femenina impone los emblemas a enfermeros de FET, y de las JONS. Yugo, 1944, ene 15; 6.

45. Bernabeu Mestre J. Madres y enfermeras. Demografía y salud en la política poblacionista del primer franquismo 1939-1950. Rev Demografía Histórica. 2002; 20(1):123-44.

46. Un curso de Enfermeras de FET y de las JONS Yugo, 1944, feb 11; 4 .

47. Jiménez Lucena I, Ruíz Somavilla MJ. Un espacio para mujeres: el servicio de divulgación y asistencia 
sanitario-social en el primer franquismo. Historia Social. 2001; 39: 67-86.

48. Inauguración del curso oficial de enfermeras de FET y de las JONS. Yugo, 1944, mar 2; 7.
49. Un curso de enfermeras de FET y de las JONS. Yugo, 1944, feb 11; 8.

50. La Delegada Nacional de la S.F. entrega los carnets a cincuenta enfermeras. Yugo, 1944, septiembre 3; 6 . 